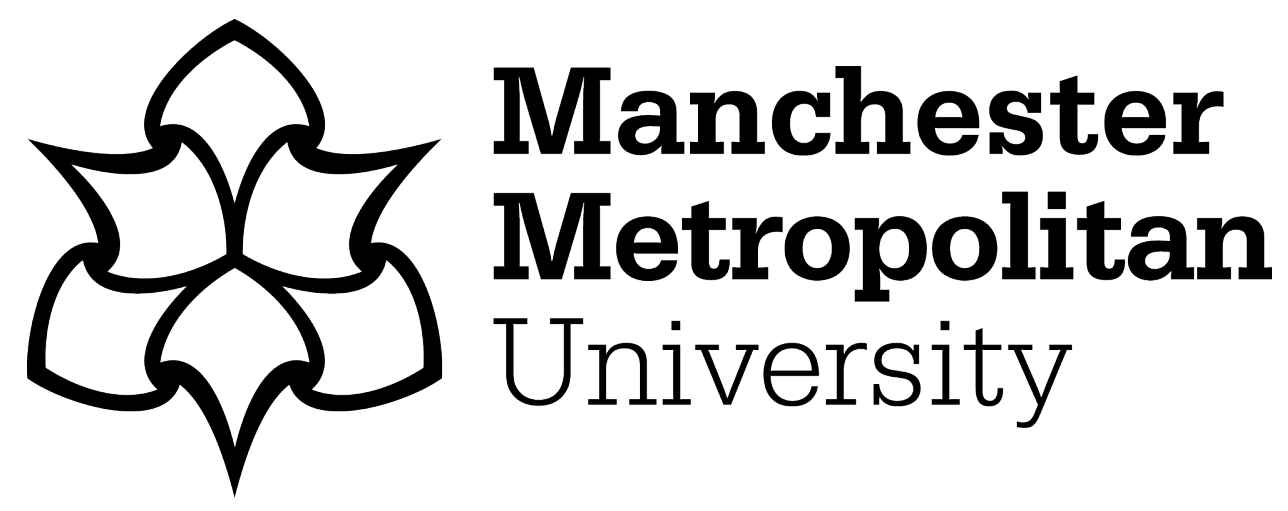

Lynch, Samantha and Barnes, Liz (2020) Omnichannel fashion retailing: examining the customer decision-making journey. Journal of Fashion Marketing and Management: An International Journal, 24 (3). pp. 471-493. ISSN 1361-2026

Downloaded from: https://e-space.mmu.ac.uk/625697/

Version: Accepted Version

Publisher: Emerald

DOI: https://doi.org/10.1108/jfmm-09-2019-0192

Please cite the published version 


\title{
Omnichannel fashion retailing: examining the customer decision-making journey
}

\author{
Samantha Lynch \\ Independent Researcher, Cirencester, UK, and
}

Liz Barnes

Manchester Fashion Institute, Manchester Metropolitan University, Manchester, UK

\begin{abstract}
Purpose - The purpose of this paper is to examine the customer decision-making journey of high involvement female fashion consumers in the context of omnichannel fashion retailing. Design/methodology/approach - The research is qualitative in nature, using a multi-method approach consisting of focus groups, semi-structured interviews, online diaries and follow-up interviews, with grounded theory applied to analyse the data.
\end{abstract}

Findings - The results of the study include a framework to outline the stages of the omnichannel customer decision-making journey for young high involvement female fashion consumers. The findings also reveal that an omnichannel decision-making journey is the one that predicated on risk and that consumers employ specific strategies to avoid such risks.

Research limitations/implications - Due to the nature of this research, the sample size is limited and may not be generalised. Data collection was confined to Manchester, UK.

Practical implications - Customer journey mapping enables practitioners to view the entire shopping experience through the eyes of the customer and enables retailers' fault-find issues within the customer and brand experience.

Originality/value - The paper advances knowledge about fashion and consumer behaviour. The customer decision journey framework maps the emotional experiences, devices and channels encountered by high-involvement fashion consumers across each stage of the omnichannel journey.

Keywords Consumer behaviour, Decision making, Fashion retailing, Risk, Omnichannel, Customer journey Paper type Research paper

1. Introduction

The concept of omnichannel retailing is geared towards serving customers when and how they want. This has been to the extent that the development and challenges of omnichannel retailing are now so fast and defected that they are no longer related to the more siloed perspective of multichannel theory (Picot-Coupey et al., 2016). Today's consumers are now routinely engaging with multiple channels and devices, making a single shopping journey more complex (Mintel, 2014, 2015; Retail Systems Research, 2013). Despite this, the consequences of cross-channel experiences are still worryingly unknown (Kollmann et al., 2012; Piercy, 2012). Omnichannel, therefore, provides a specific mandate to explore how the proliferation of retail channels fit into a decision-making journey for fashion.

The motivation to research omnichannel is compelling since customers exhibit greater loyalty and spend at least $20 \%$ more than their multichannel counterparts (Bodhani, 2012; IDC Retail Insights, 2010). From a theoretical standpoint, omnichannel is an emerging literature theme within retail marketing (Lazaris and Vrechopoulos, 2014a; Piotrowicz and Cuthbertson, 2014; Savastano et al., 2016). However, the concept has yet to mature despite its importance within the retail industry (Bernon et al., 2016; Verhoef et al., 2015). While extant research has implied a focus on distribution and logistics (Christopher, 2016; Hu€bner et al., 2016; Murfield et al., 2017) there is scope to examine omnichannel retailing through the lens of the customer. Research grounded in decision-making theory is therefore well-placed to achieve a customer-centric view of omnichannel decision-making. For fashion, Barnes (2013: 201) asserts that, "future fashion marketing research in the area of omni-channel is likely to be highly valued by practitioners". Fashion consumer behaviour has changed as a result of the development technology and there is a need for research to examine how customers are interacting and engaging with a variety of different channels as part of the overall decision- making journey. The timely need for such research is driven by fashion retailers who are now looking to achieve best practice in their omnichannel offering. 
The aim of the paper is to examine the stages of decision-making in the omnichannel shopping journey for young, high involvement female fashion consumers. The objectives are: to review the theoretical foundation of consumer decisionmaking in the omnichannel context; to examine how the shopping behaviour of high-involvement female fashion consumers has changed and the impact this has on decision-making, specifically in terms of perceived risk and brand; to analyse themes from the data collection to develop a theoretical framework that refines, evaluates and reflects decision-making journey. The study will bring together the research by means of literature gaps identified in a customer decision-making journey framework that correlates high involvement with stage, channel and device usage across the journey along with consumers' affective experiences. With a systemic investigation, this decision-making and customer-centric perspective expands the current scope of omnichannel retailing and fashion consumer research.

\section{Literature review}

Retailing business models have evolved during the past decade to reflect the increase in the breadth of channels and the changes in shopper behaviour (Brynjolfsson et al., 2013; Verhoef et al., 2015). The study therefore draws and synthesises three literature streams: omnichannel retailing, fashion consumer behaviour and decision-making.

\subsection{Omnichannel}

Table 1 provides a summary of the dimensions of the definition for omnichannel. The concept depicts a customer journey that requires retailers to operate in a seamless and synergistic way across all retail formats (Kent et al., 2016; Levy and Weitz, 2014; Bhalla, 2014; Verhoef et al., 2015). Studies also suggest that omnichannel is about delivering an integrated customer experience which combines the advantages of several different channels all within a single customer journey (Bernon et al., 2016; Brynjolfsson et al., 2013; Piotrowicz and Cuthbertson, 2014; Rigby, 2011; Verhoef et al., 2015; Elliott et al., 2012; Frazer and Stiehler, 2014). This blurring of lines means the natural borders of physical and digital retail environment have dispersed, whereby consumers can combine channels to create the most optimum of mix of hedonic experiences and utilitarian activities. The definition of omnichannel has consequences for operational retail strategy, since the approach digresses away from the more silo-like perspective multichannel retailing research (Nicholson et al., 2002; Hsieh et al., 2012).

To achieve a single view, research has called for a more complete view outlining the customer's buying process and the channel demands and preferences at each stage of the decision process (Peterson et al., 2010; van Bruggen et al., 2010). Through exploring existing literature on omnichannel and multichannel, it is evident that there are several different perspectives from which the concept of omnichannel can be viewed, as shown in Table 2.

\section{Table $1 \& 2$ Here.}

Table 1 Dimension of Omnichannel Concept Definition

\begin{tabular}{|c|c|}
\hline Dimension & References \\
\hline Seamless customer experience (blurred and integrated) & $\begin{array}{l}\text { Frazer and Stiehler, 2014, Hsieh et al., (2012), Brynjolfsson et al. } \\
\text { (2013), Parsons and Descatoires (2016), Alexander and Alvarado } \\
\text { (2014), Lazaris and Vrechopoulos (2014a; 2014c), Picot-Coupey } \\
\text { and Piveteau (2016), Verhoef et al. (2015), Bernon et al. (2016), } \\
\text { Piotrowicz and Cuthbertson (2014) }\end{array}$ \\
\hline Customer-centric, single view of the customer & $\begin{array}{l}\text { Kitchen and Schultz (2009), Deloitte (2012), Breidbach et al, } \\
\text { (2014), Kim et al. (2014), Picot-Coupey et al. (2016), Shaw and } \\
\text { Towers (2015), Cummins et al. (2016), Rigby, 2011, Savastano et } \\
\text { al. (2016), Peltola et al. (2015), Mirsch et al. (2016), Bernon et al. } \\
\text { (2016), Kim et al. (2014), Hoogveld and Koster (2016), Piercy } \\
\text { (2012) }\end{array}$ \\
\hline Brand experience and engagement & $\begin{array}{l}\text { Hansen and Sia (2015), Cummins et al. (2016), Picot-Coupey et al. } \\
\text { (2016), Rangaswamy and van Bruggen (2005), Savastano et al. } \\
\text { (2016) }\end{array}$ \\
\hline Simultaneous channel usage & $\begin{array}{l}\text { Lazaris et al. (2015), Mirsch et al. (2016), Hure et al. (2016), } \\
\text { Verhoef et al. (2015) }\end{array}$ \\
\hline
\end{tabular}




\begin{tabular}{|l|l|}
\hline Channel agnostic & $\begin{array}{l}\text { McCormick et al. (2014), Aubrey and Judge (2012), Bhalla (2014) } \\
\text { Lonsistency }\end{array}$ \\
Holistic & $\begin{array}{l}\text { Lazaris and Vrechopoulos (2014c), Hure et al. (2016), Mirsch et al. } \\
\text { (2016), McCormick et al. (2014), Melero et al. (2016) } \\
\text { (2014), Breidbach et al. (2014), Savastano et al. (2015), Bernon et } \\
\text { al. (2016), Blazquez (2014) }\end{array}$ \\
& $\begin{array}{l}\text { McCormick et al. (2014), Savastano et al. (2015), Aubrey and } \\
\text { Judge (2012), Blakeney (2016), Melero et al. (2016), Kim et al. } \\
\text { (2014), Barnes (2016), Parsons and Descatoires (2016), Alexander } \\
\text { and Alvarado (2014) }\end{array}$ \\
\hline
\end{tabular}

Table 2 Empirical research perspectives to explore omnichannel

\begin{tabular}{|c|c|}
\hline PERSPECTIVE OF STUDY & AUTHORS \\
\hline Human computer interaction & Peltola et al. (2015), Lazaris and Vrechopoulos (2014b) \\
\hline Service & $\begin{array}{l}\text { Piotrowicz and Cuthbertson (2014), Savastano et al. (2016), Lazaris } \\
\text { et al. (2015), Patrıcio et al. (2008), Verhoef et al. (2015), Peltola et } \\
\text { al. (2015) }\end{array}$ \\
\hline Customer management & $\begin{array}{l}\text { Neslin et al. (2006), Neslin and Shankar (2009), Verhoef et al. } \\
\text { (2007), Savastano et al. (2016), Stone et al. (2002 }\end{array}$ \\
\hline Customer experience & $\begin{array}{l}\text { Peltola et al. (2015), Frazer and Stiehler (2014), Piotrowicz and } \\
\text { Cuthbertson (2014), Mirsch et al. (2016), Aubrey and Judge } \\
\text { (2012), Blazquez (2014), Verhoef et al. (2009), Rose et al. (2012), } \\
\text { Stone et al. (2002), Grewal et al. (2009) }\end{array}$ \\
\hline Customer journey & $\begin{array}{l}\text { Peltola et al. (2015), Wolny and Charoensuksai (2014), Patrıcio et } \\
\text { al. (2011), Alexander and Alvarado (2014) }\end{array}$ \\
\hline Retail (marketing and strategy) & $\begin{array}{l}\text { Lazaris and Vrechopoulos (2014a; } 2014 \text { c), Hure et al. (2016), } \\
\text { Savastano et al. (2016), Verhoef et al. (2015), Berman and Thelen } \\
\text { (2004), McGoldrick and Collins (2007), Pookulangara et al. (2011), } \\
\text { Dholakia et al. (2005), Schramm-Klein et al. (2011), Neslin and } \\
\text { Shankar (2009), Chatterjee (2010) }\end{array}$ \\
\hline & $\begin{array}{l}\text { Bernon et al. (2016), Carvalho and Campomar (2014), Hubner et } \\
\text { al. (2016) }\end{array}$ \\
\hline Retail (supply chain, logistics and operations & \\
\hline Consumer behaviour (including fashion-specific studies) & $\begin{array}{l}\text { Blazquez (2014), Aubrey and Judge (2012), Wolny and } \\
\text { Charoensuksai (2014), Alexander and Alvarado (2014), McCormick } \\
\text { et al. (2014), Kent et al. (2016), Alexander and Alvarado (2014) }\end{array}$ \\
\hline Branding and brand experience & $\begin{array}{l}\text { Schoenbachler and Gordon (2002), Aubrey and Judge (2012), } \\
\text { Piotrowicz and Cuthbertson (2014), Savastano et al. (2016), } \\
\text { Mirsch et al. (2016), Hansen and Sia (2015), Jones and Runyan } \\
\text { (2013), Nicholson et al. (2002), Kwon and Lennon (2009), Verhoef } \\
\text { et al. (2015 }\end{array}$ \\
\hline
\end{tabular}

Though there has been a surge in the omnichannel literature there is still a paucity. There is still a paucity of the research literature that understands how different types of channels map out as a cognitive decision path and which view this from 
the customer perspective. The multichannel customer management framework by Neslin et al. (2006) offers an important starting point as it recognises cross-channel interactions and the linkages with decision- making but is not specific to fashion consumers. Linking omnichannel and decision-making theory together provides a foundation to explore omnichannel customer journeys in depth and views this through the eyes of the customer.

\subsection{Fashion}

Omnichannel is one of the most significant innovations in the fashion industry (Drapers, 2014a). Currently, fashion brands do not have the "glue" they need to link all the channels together, and the result is a negative experience for the customer and lost sales (Kurt Salmon, 2014). Compounding this issue is the knowledge that the extent of involvement in a fashion purchase decision influences the length and stages of the decision-making process (Jordaan et al., 2006; Solomon and Rabolt, 2009). Fashion clothing involvement is a significant arbiter on the time spend on deciding and committing to a fashion purchase and heightens marketing, advertising information search interest (Hourigan and Bougoure, 2012; Vieira, 2009). This is important as high-involvement consumers are traversing different channels at different stages of the fashion shopping journey and as part of an overall decision-making encounter. Fashion marketing research on the subject of omnichannel is emerging, centring upon the impact of technologies on the store environment such as Alexander and Alvarado (2014) and Kent et al. (2016). There is now scope for research contributions which explore omnichannel fashion consumer behaviour to provide insights to decision journeys of different customer segments. The fashion category adds a unique dimension to omnichannel study and the customer decision-making journey due to the interplay between fashion and an individual's self-concept. Indeed, Park and Stoel (2005) assert that clothing is a high-risk product category for a consumer. To implement an omnichannel fashion retail strategy there needs to be a clear understanding of customers' decision-making stages for fashion and the role of risk and brand along that journey, therefore, fashion consumer behaviour merits dedicated attention within omnichannel retail research.

\subsection{Decision-making}

The cognitive dimension of consumer behaviour recognises purchase decision-making as a problem-solving process with multiple steps (Schr€oder and Zaharia, 2008). There have been several iterations of the consumer decision process, for example Blackwell et al. (2006). However, theories on consumer behaviour of the pre-internet decision process have remained virtually unchanged and largely unquestioned (Wolny and Charoensuksai, 2014). Similarly, Parsons and Descatories (2016) suggest there is a timely need to re-examine the appropriateness of consumer decision-making models. This contrasts with other consumer behaviour concepts such as customer engagement which has seen significant development over the past decade. A summary of recent decision-making studies, which highlights the emerging focus of decision-making in multichannel research, is shown in Table 3. However, with the emergence of omnichannel, decisionmaking journeys have become more complex and research has perhaps stagnated research in proposing practical models to unravel the complexities of consumer decision-making journeys.

In parallel to the established consumer decision process model of Blackwell et al. (2006), the customer journey is a newer concept which has the potential to bridge this gap between decision-making and omnichannel. Wolny and Charoensuksai's (2014) application of Molenaar's (2012) ORCA model usefully identified stages of the shopping journey and channels used for cosmetics which is exemplified by preferences for channels at different stages of the buying process and one which reflects the emotional, cognitive and behavioural drives. Meanwhile, Crosier and Handford (2012) also proposed a customer journey model, though not originally designed for retail, which highlights the richness customer journey studies can offer by capturing the temporal, emotional and linked events to gain an overview of the overall customer experience. Studies have called for the research to revisit consumer decision-making models to understand the different functions that channels serve at different stages of decision process (Nicholson et al., 2002) and for further research on understanding consumer behaviour across channels and omnichannel retailing (Alexander and Alvarado, 2014; Bhalla, 2014; Blazquez, 2014;

Brynjolfsson et al., 2013; Kent et al., 2016; Lemon and Verhoef, 2016; Merrilees, 2016; Piotrowicz and Cuthbertson, 2014; Verhoef et al., 2015). Hence, this research attempts to bring together these frameworks along with the work by Neslin et al. (2006) to answer the research aim. By comprehensively exploring the array of channels this research will reflect the highinvolvement consumer reality, whereby channels are no longer used in isolation of one another but, instead, used together as part of an overall decision- making encounter. The work seeks to contribute to knowledge on retail marketing and consumer behaviour by providing a framework which maps the omnichannel customer decision-making journey for fashion. The current study is positioned as a study of depth and with raises consciousness of participants to think about the decision steps taken across a fashion shopping journey. In addition, the study will correlate high involvement with the omnichannel for fashion and consider how this translates into the omnichannel decision journey for fashion in terms of the stages, channels and devices employed and affective experiences.

Table 3 Summary of Decision -Making Studies 


\begin{tabular}{|c|c|c|}
\hline Author & Description & Findings \\
\hline Cho and Workman (2011) & $\begin{array}{l}\text { Fashion and multichannel-survey } \\
\text { conducted of male and female } \\
\text { university students. Study examines } \\
\text { whether gender, fashion innovativeness } \\
\text { and opinion leadership, and need for touch } \\
\text { has an effect on consumers' multi-channel } \\
\text { choice and touch/non-touch shopping } \\
\text { channel preference in clothing shopping }\end{array}$ & $\begin{array}{l}\text { Multichannel decision choice influenced by } \\
\text { fashion innovativeness and opinion } \\
\text { leadership } \\
\text { Irrespective of gender fashion } \\
\text { innovativeness and opinion leaders those } \\
\text { who used more than one channel } \\
\text { preferred online, TV and cataglogue } \\
\text { channels }\end{array}$ \\
\hline Park and Cho (2012) & $\begin{array}{l}\text { Fashion-an empirical survey study using } \\
\text { female university student to understand } \\
\text { how social media } \\
\text { communities can affect information } \\
\text { seeking behaviour and decision-making for } \\
\text { apparel shopping }\end{array}$ & $\begin{array}{l}\text { Positive relationship identified between } \\
\text { commitment to a social media community } \\
\text { and information seeking behaviour at the } \\
\text { community Commitment is developed } \\
\text { when individuals are psychologically } \\
\text { attached to the community }\end{array}$ \\
\hline Puccinelli et al. (2009) & $\begin{array}{l}\text { The customer experience-literature based } \\
\text { paper examines of specific } \\
\text { aspects of consumer behaviour and } \\
\text { their role in the consumer decision process }\end{array}$ & $\begin{array}{l}\text { Need recognition encompasses, goals, } \\
\text { involvement and affect. Information search } \\
\text { considers goals, memory, involvement and } \\
\text { affect. Evaluation features goals, memory, } \\
\text { involvement, attitudes, affect, } \\
\text { atmospherics, attributions and choices. } \\
\text { Purchase includes: goals, attitudes, affect, } \\
\text { atmospherics, attributions. Post- purchase } \\
\text { considers same elements as purchase }\end{array}$ \\
\hline & & $\begin{array}{l}\text { Key finding: motions affect (moods and } \\
\text { emotions) influence all stages of consumer } \\
\text { decision process }\end{array}$ \\
\hline Balasubramanian et al. (2005) & $\begin{array}{l}\text { Multichannel-customer interview study to } \\
\text { identify that consumers } \\
\text { employ different channels and media } \\
\text { at different stages of the decision process }\end{array}$ & $\begin{array}{l}\text { Development of a conceptual framework } \\
\text { to delineate the utilities consumers device } \\
\text { from channels (economic, quest for self- } \\
\text { affirmation, quest for symbolism, quest for } \\
\text { social interaction, reliance on schemas and } \\
\text { scripts) }\end{array}$ \\
\hline & & $\begin{array}{l}\text { Consumers will traverse across channels } \\
\text { across during a decision process }\end{array}$ \\
\hline Nicholson et al. (2002) & $\begin{array}{l}\text { Multichannel-exploration of consumer } \\
\text { decision-making and selection across } \\
\text { multiple channels using female consumers } \\
\text { in focus group research and shopping } \\
\text { diaries }\end{array}$ & $\begin{array}{l}\text { Identification of situational variables based } \\
\text { upon a Belkian analysis. Call for research to } \\
\text { revisit consumer decision- making models } \\
\text { to understand the different functions that } \\
\text { channels serve at different stages of } \\
\text { decision process }\end{array}$ \\
\hline Neslin et al. (2006) & $\begin{array}{l}\text { Multichannel-a conceptual paper to } \\
\text { propose a framework for multichannel } \\
\text { customer management to address } \\
\text { challenges (including consumer behaviour } \\
\text { challenges) and depicts the linkages } \\
\text { between them }\end{array}$ & $\begin{array}{l}\text { Framework can be used to map which } \\
\text { channel is used at which stage of the } \\
\text { decision process to better co-ordinate } \\
\text { channels and is based on consumer } \\
\text { decision process }\end{array}$ \\
\hline & & $\begin{array}{l}\text { Study highlights determinants of channel } \\
\text { selection including situational factors and } \\
\text { individual difference }\end{array}$ \\
\hline Wolny and Charoensuksai (2014) & $\begin{array}{l}\text { Decision process and customer journey- } \\
\text { qualitative interview study exploring the } \\
\text { integration of multiple channels into the } \\
\text { decision process. Highlights that customer } \\
\text { decision process models have remained } \\
\text { unquestioned despite the development of } \\
\text { the digital marketing discourse. Employs } \\
16 \text { diaries, sample employed for diaries }\end{array}$ & $\begin{array}{l}\text { Identifies the need for multichannel } \\
\text { journey's to be mapped } \\
\text { Identification of key channel influences } \\
\text { across different stages of decision-making }\end{array}$ \\
\hline
\end{tabular}




\begin{tabular}{|l|l|l|}
\hline & $\begin{array}{l}\text { also used for 16 interviews. Study focused } \\
\text { on beauty context }\end{array}$ & $\begin{array}{l}\text { Segments customer journeys into three } \\
\text { distinct patterns }\end{array}$ \\
& & \\
\hline
\end{tabular}

\section{Methodology}

Based on the current literature there exists an opportunity to provide an in-depth qualitative study. Being positioned as a study of depth the research employed a four-phase multi-method approach since only a limited application of multi-method approaches have been used in empirical omnichannel studies for example, Alexander and Alvarado (2014) and Wolny and Charoensuksai (2014). Table 4 provides summary of each stage of the research. Phase one focus groups (Patton, 2002) enabled participants to share their experiences and expectations on omnichannel fashion retailing. During phase two semistructured interviews (Malhotra, 2010) featuring photo-elicitation (PE) took place where participants mapped their omnichannel customer decision-making journey. Phase three enabled participants to evidence the fashion shopping encounters through an online blog diary (Nicholson et al., 2002; Schr€oder and Zaharia, 2008). At the phase four follow-up interviews of participants (Belk et al., 2013; Lowrey et al., 2005; Xia, 2010) were probed further based on their blog diaries responses and prior phases of data collection.

The purposive sample for the study was confined to Manchester, UK, consisting of female fashion consumers aged 18 to 24 (McCormick and Livett, 2012). The study sought participants who were high-involvement fashion consumers and these were recruited from the University of Manchester. In order to identify the extent of an individual's involvement for this study fashion involvement was understood as a continuum from apathetic (uninvolved); moderate (less motivated); enthusiast (highly involved) (Cardoso et al., 2010). Participants were identified as high involvement consumers on the basis of those who view branding as important to them, who regularly purchase clothing at least once per month, who perceived that apparel has a self-expressive function and who emphasised the importance and sensitivity to choosing the right product (Cardoso et al., 2010; Hourigan and Bougoure, 2012; Jordaan et al., 2006; Kim, 2005; Koller and Salzberger, 2006; Summers, 1970). Participants were carried through the multi-method approach in order to probe deeper and deeper at each stage. By producing such connected phases of data collection, the data collection process became a journey. In essence, each phase of the data collection was a point of reflection and a refinement process to build a picture of the omnichannel decisionmaking journey and so, the phases of the study become greater than the sum of their parts.

The qualitative data were then analysed using a grounded theory approach in order to identify patterns across the breadth of the dataset. The research recognises both purist approaches to grounded theory analysis - where the findings are purely derived from the primary data and approaches which acknowledge the role and importance of existing theories and the literature that have a valid role to play in theory formation McCracken (1998). This research recognises that there is a continuum or scale as to the strength of the grounded theory approach and it is the decision of the researcher as to which level of concentration of grounded theory they choose to apply. This is supported by Corbin and Strauss (2015, p. 383) "since no researcher enters into the research process with a completely blank mind". Whilst grounded theory analysis is an organic process, the significance of structure is still recognised through the coding process. The research data were carefully analysed using the approach of Glaser and Strauss (1967) three-step process of: open coding-data disaggregation and reorganisation into labelled units; axial coding-recognition, establish, evidence and explain the relationship between primary categories and sub-categories; selective coding integration of categories into principle categories which underpin the theory proposed. As the comparison takes place, new codes will be created and existing codes reanalysed, as any new codes come to light. The data were analysed using Microsoft Excel to maintain closeness to the data, in line with La Pelle (2004) and Ryan (2004). Themes, patterns and categories emerged and were refined further at each phase of the data collection.

Table 1 Phases of Research Summary

\begin{tabular}{|l|l|l|l|l|}
\hline & $\begin{array}{l}\text { Phase 1 } \\
\text { Focus Groups }\end{array}$ & $\begin{array}{l}\text { Phase Two } \\
\text { Semi-Structured } \\
\text { Interviews + PE }\end{array}$ & $\begin{array}{l}\text { Phase Three } \\
\text { Online Blog Diary }\end{array}$ & $\begin{array}{l}\text { Phase 4 } \\
\text { Follow-Up Interview }\end{array}$ \\
\hline No. of Participants & $5-7$ per focus groups & 11 & 7 & 6 \\
\hline Duration & 60 mins & $45-60$ mins & 4 weeks & $15-25$ mins \\
\hline
\end{tabular}




\section{Findings and analysis}

In accordance with the research aim and objectives careful analysis of the multi-method study allowed decision journey themes and patterns to emerge which culminated in a new framework for omnichannel decision-making. An integrated findings and analysis discussion provide an overview of the final framework and consider key themes in detail.

\subsection{A framework for the omnichannel customer decision-making journey for fashion}

In pursuit of the research aim, the study contributes to knowledge by providing an omnichannel consumer behaviour-based journey model which extends beyond the original consumer decision process. The framework presents an in-depth account of high-involvement consumers' decision-making journey specifically for fashion. The framework in Figure 1 builds upon the consumer decision process of Blackwell et al., (2006), early work on the study of the customer journey by Wolny and Charoensuksai, (2014) and multichannel customer management framework proposed by Neslin et al., (2006). The findings indicate an enhanced range of decision-making stages, channels and devices used at each stage and highlight the affective experience of high-involvement fashion consumers along the journey. The framework also highlights the characteristics, moderators and expectations at the outset of this decision-making path and resultant outcomes including satisfaction, an enhanced brand relationship, trust and loyalty.

\subsection{Expectations of an omnichannel decision-making journey}

The omnichannel concept is one borne out of high-involvement consumers' heightened expectations of shopping across an array of channels for fashion. The findings around expectations signify that shoppers have become so accustomed to traversing retail channels that their expectations of those encounters have increased. Fashion consumers expect seamlessness and consistent experiences, and these heightened expectations serve as a distinguishing feature of omnichannel strategies versus a traditional multichannel approach. Uniquely the results explain how a seamless and consistent experience manifests from customer's point of view, as follows:

4.2.1 Seamless customer experience. For the study's participants a seamless customer experience manifests as a decision journey which is free of "glitches" that may interrupt the flow of the encounter. Shoppers have also come to expect minimal delivery lead times and free delivery, in order to proceed to purchase. "I've just become much more demanding of free delivery, delivery times [. . . ]" (Fg) However, consumers did state that they were open to pay for delivery subscriptions. This is a mutually beneficial option for both brand and consumer as it absorbs some fulfilment costs and provides added convenience. Furthermore, this option may facilitate loyalty since consumers may choose to shop at a brand more because of already having a subscription.

Another seamless expectation was around a smooth transition between and among different retail channels. For example, "There's no glitches between, so if I've seen that online ifitlooksnicelcangointotheshopandtryitonorlcanorderitonline, tryitonathomeand send it back" (Fg). This too was the case for returns as shoppers expect to be able to return items to any channels and particularly the store. However, participants expressed that expectations were not always met and recounted difficulties in returning to a different channel than where they purchased. "I like to be able to purchase online but return to a store, so I can get an immediate refund or exchange. [Retailer] do not offer this therefore I will not purchase online from them" (Bp). Omnichannel is about being on-demand this means wherever and however the customer chooses. The findings confirm the recent work by Bernon et al. (2016) that returns to store is still the preferred return option for customers but also assert the importance of this for fashion purchases. Another expectation was that shoppers should not have to re-enter personal details when changing channels. The finding agrees with Shaw and Towers (2015) who identify that consumers make use of technology principally to remember details. "I like stores to remember me when I use any channels so when I come back I don't need to enter the details over again" (Bp). In a similar vein, the findings importantly also uncovered implications related to the use of customer wishlists and baskets with participants stating that the information they store should be accessible regardless of the channel used. Therefore, retailers must develop systems to support a single view of the customer not only for operational reasons but to support the flow of the purchase for the fashion consumer.

4.2.2 Consistent brand. Consistency is a dimension of the omnichannel concept and refers to the consistency of the brand (Picot-Coupey et al., 2016). The results reveal how consistency manifests from the perspective of the consumer and specifically concern the promotional mix. Fashion consumers expect a consistent brand regardless of the channel used and emphasised the need for elements of the brand identity: fonts, social media filters, artwork, logos and messages to be of a consistent style across channels, "So that's why it's important, that it's consistent [. . . ] if it's not, it can become really confusing and can really isolate you [. . . like you don't want to be a part of something that isn't quite clear" (Fi). This is 
important since omnichannel consumers seek to render a clear brand image in their own mind and brand identity elements which are inconsistent could make an individual question the brand. The findings suggest that consistency of the brand identity reduces risk for the fashion consumer. Within an omnichannel decision-making journey, each channel contributes to an overall interaction with the brand, and this experience is greater than the sum of its individual parts and supports the idea of omnichannel consumers being channel agnostic.

Participants spoke of the need for reinforcement of marketing communications and information across channels to enable decision-making. For example, "I really enjoyed my experience in [. . .] and I felt that the key trends which they featured on their mannequins and in their window displays reflected the themes of their website/mobile apps" (Bp). Fashion retailers also have a responsibility to ensure that products shown online accurately represent the physical garments. "[. . .] I like to make sure that the colours and the style looks the same across all of the channels and make sure that everything looks the same" (In). Another expectation was consistency of stock, "[...] marketing communications need to clearly identify if a product is a channel exclusive, even if that means it is a store exclusive" (In). The same expectation was reported for pricing and there were still instances where participants found inconsistent pricing across channels.

\subsection{Stages of the decision-making journey for fashion}

The findings of the study articulate the stages of the omnichannel customer journey for fashion (Figure 1). At pre-purchase new stages emerged: inspiration, research and comparison. The impact of the results reflects a much richer view and more complex view of fashion consumer decision-making particularly at post-purchase, building upon the work by Blackwell et al. (2006) and Neslin et al. (2006). There was an increased emphasis on the post-purchase decision-making stages to emphasise shopping in remote channels with the new stages of: delivery, returns, show and share.

4.3.1 Pre-purchase. In the interview phase shoppers mapped the stages of their decision journey. Participants articulated the inspiration stage as instances to learn about new styles and to acquire ideas about what to buy, for high-involvement consumers this was part of their everyday. "That'd be one group, so that'd be my inspiration, what gives me ideas of what I want to buy" (In). The study builds upon the finding by Workman and Studak (2006) that fashion opinion leaders will have a want rather than need-based approach to problem recognition. The identification of the inspiration stage highlights the importance of technology in providing fashion inspiration for consumers (Alexander and Alvarado, 2014; McCormick and Livett, 2012) and agrees with Wolny and Charoensuksai (2014) who identify the orientation/inspiration/horizon-scanning stage where consumers are scanning the marketplace.

The research and comparison stage depicted the point at which shoppers were searching for information and comparing a specific type of product. "Then I would say the website searching and the comparison" (In). Shoppers described research and comparison activities occurring at the same time and this reflects the influence of technology in making the customer decision-making journey more efficient which contrasts the earlier decision-making models by Blackwell et al. (2006). Importantly, another reason for the combined research and comparison stage was participants' desire to check they had seen everything available before going to try an item on and evaluate it. Consumers did not feel that their shopping journey was complete without using an array of channels to research and compare and to ultimately reach a saturation point: "I like to use the multiple channels to check that I have seen everything" (In). This presents a new insight as essentially these high involvement consumers experience FOMO (fear of missing out) decision behaviour and traverse channels in an omnichannel journey as a means of a risk reduction strategy. The extent of the need to reach saturation connects with empirical findings that high-involvement consumers are maximisers and are more sensitive to regret (Cui et al., 2009; Kasper et al., 2010; Koller and Salzberger, 2006).

The evaluation stage emphasised the need for tactile evaluation where consumers would try-on the product. "The next stage, it's go to the shop and try it on" (Fg). The results reinforced the nature of the study's sample since high-involvement female consumers still require the need for tactile input when shopping for fashion review of the product's physical attributes (Cho and Workman, 2011; Citrin et al., 2003) and also concurs with Wolny and Charoensuksai (2014). What the results also show is that the omnichannel shopping journey ...

Figure 1 The Omnichannel Customer Decision Journey Framework for Fashion 


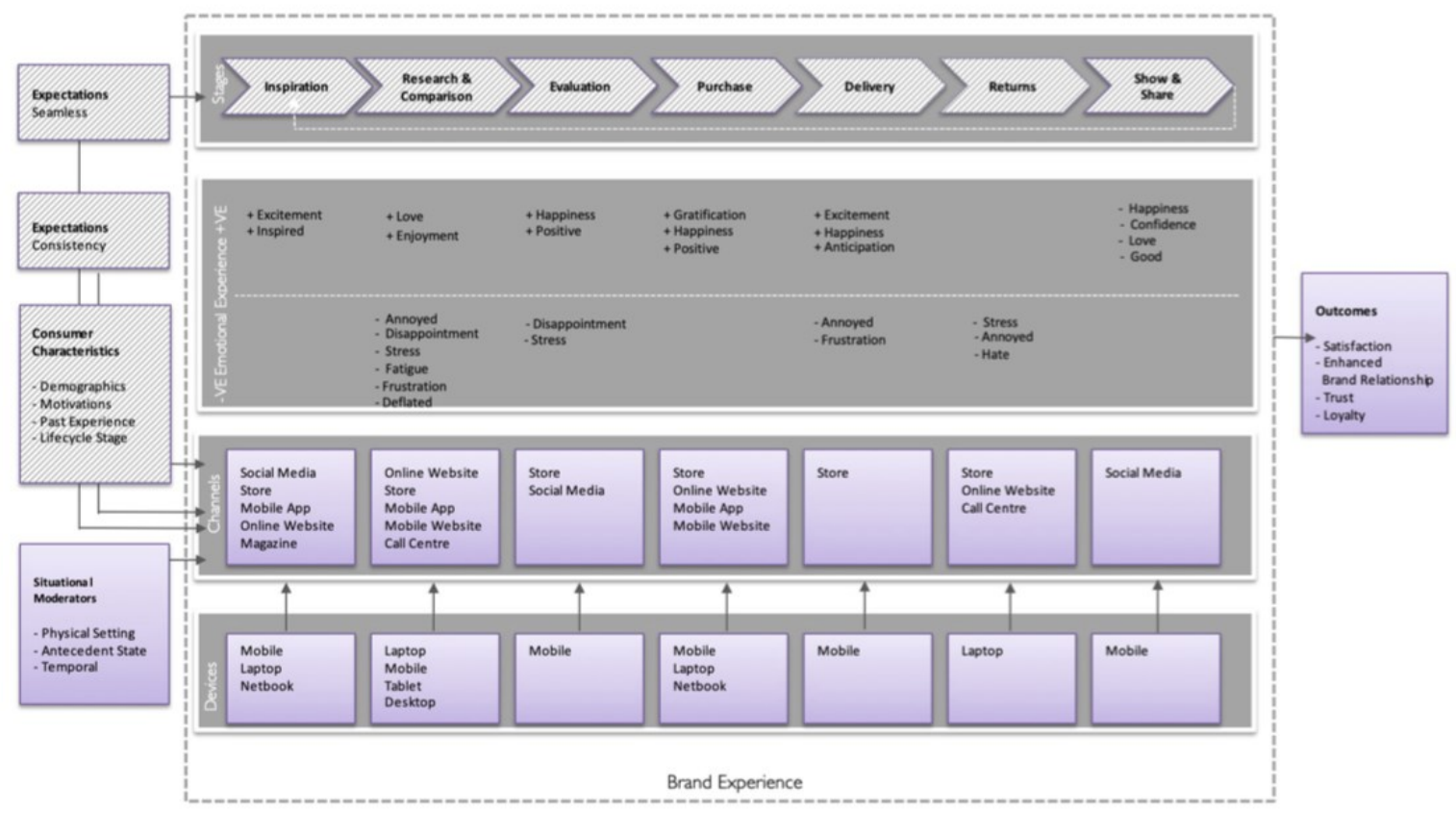

$\ldots$ is a distinctly social experience. For example, participants would actively seek the opinions of others before purchase by sharing images and links of the fashion product. "But this is the final approval, and this is the approval before the purchase [. . .]" (In). The strength of social media at this point was to the extent that shoppers would disregard the same product following a negative evaluation from peers. "I was in the middle of the shop and thought I would [...] send it to 20 people to see if it was a good idea and it wasn't [...], so I did no't buy it" (Fg). The findings also correlate with the practitioner literature by Shaw and Towers (2015) that identified that millennial consumers would ask for feedback prior to purchase. Hence the evaluation stage identifies further risk minimising behaviour by high-involvement consumers and sheds new light on the work of Koller and Salzberger (2006) and Koller et al. (2007) on pre-purchase dissonance. The evaluation stage also highlighted the digital benefits of shopping for fashion online by using wishlists and basket functions as participants indicated this as a way to collate, curate and consider potential items for purchase. "I also use the wishlist tool to add products to a list of items I am considering buying" (Bp). Wishlists and baskets were also used by high-involvement shoppers to serve as an end point in the fashion shopping journey when users were unable or did not want to purchase the product selections at that point. "You're just scrolling through, creating a basket which you do no't necessarily buy" (Fg). Hence why evaluation rather than pre-purchase evaluation was the label for this stage, since journeys for this segment may not always result in a purchase.

The purchase stage identified the point at which consumers are ready to buy an item. This stage was consistent with the empirical literature (Blackwell et al., 2006; Neslin et al., 2006; Wolny and Charoensuksai, 2014). As part of going through the purchase process, participants explained that they would search for promotional discounts or offers in order to reduce the cost of the item. This demonstrates that omnichannel consumers are empowered seeking the best deal and desires to once again minimise the risk of FOMO on a better or cheaper alternative.

4.3.2 Post-purchase. The data collection revealed rich insight about post-purchase decision-making. The current findings build upon the multichannel customer management framework of Neslin et al. (2006) and beyond to mark out a complex post-purchase decision journey featuring the stages of: delivery; returns; show and share. At delivery, shoppers recounted decisions around the most optimum delivery method and discussed the lag between ordering and receiving the item along with a lack of communication during this time. "Well I paid for it to be there by $1 \mathrm{p} . \mathrm{m}$. the next day [. . .] they were supposed to email me when it was ready to collect, and they didn't." (Fg). The research therefore extends decision-making further by marking out distinct post-purchase stages to reflect digital developments in remote shopping channels and the complexity this adds to consumer purchase decision- making. A new returns stage highlighted product-related issues for shoppers regarding size and fit. In such instances, participants demonstrated further FOMO-driven, risk-reduction strategies by overorder multiples of the same product to find the correct size, with a view to returning some. "I often find myself ordering two sizes and sending one of them back" (BP). "If I feel a bit wobbly about then I'll buy it and keep in mind that I might have to return it" (In). The current work supports Bernon et al. (2016) assertion that returns are a major challenge in current omnichannel processes. The findings of the returns stage also depict a fundamental shift in shopping behaviour, suggesting that high-involvement omnichannel fashion consumers experience delayed decision-commitment towards purchasing 
fashion. Consequently, the influence of remote digital channels needs to be accounted for in contemporary customer decision journey frameworks.

Show and share stage was one of the most consistent and richly defined decision stages of the omnichannel journey for fashion and responds to the call by Mirsch et al. (2016) for more understanding on the role of social media in the omnichannel environment. Consumers were motivated to "show-off" new purchases. For example, "You want to show the world, you'd take a photo and Instagram it" (Fg). Furthermore, it was about validation of purchase decisions "[. . .] Validating you bought something good I suppose [. . .] validating what you are doing." (In). The stage highlights how high-involvement fashion consumers want to reinforce their fashion opinion leadership publicly. The results also agree with gender studies that state high self-monitoring females tend to be fashion opinion leaders and use apparel for social approval (Auty and Elliott, 1998; Browne and Kaldenberg, 1997; Carey et al., 2014). Meanwhile the share component recognises the how fashion consumption is now intertwined with technology and recognises the desire for brand engagement as shoppers communicated their appreciation for brands. "I felt it was important to tag the retailers [. . .] I had bought my new clothes from to show appreciation and let others know where they could find these great pieces" (Bp). The show and share was the final stage discussed by participants and closes the loop in the omnichannel journey because one individual's decision journey can serve as inspiration for another. "It kind of links it back to the beginning, I guess. You're like you are serving as [. . .] inspiration for someone else" (In). These results provide further support for Carvalho and Campomar (2014) whereby consumers who interact within an omnichannel environment are more disposed to influencing others.

\subsection{Channel and device usage}

What the findings reveal is that each stage of the journey requires a different constellation of channels to provide different functions and benefits for the fashion consumer. The findings respond to calls within the omnichannel literature that the consumer's choice of method for interaction is important (Piotrowicz and Cuthbertson, 2014) and that devices should be considered as part of the a seamless shopping experience (Verhoef et al., 2015).

4.4.1 Channels. Lemon and Verhoef (2016) call for the need to understand the customer perspective of the purchase journey and to identify the specific touchpoints used. Figure 1 provides first findings and a holistic view as to how channels and devices are used across a decision-journey for fashion. For example, the emphasis of the social media channel during the inspiration, evaluation along with the show and share stages signifies the omnichannel fashion consumers' journey as a highly social experience. "I would only ever use the social media for [...] the purpose of being inspired or at the end of my shopping journey, showcasing what l've bought" (In). The use of online websites was recounted by participants as being used for both the hedonic inspiration stage but importantly for utilitarian research and comparison activities, prior to visiting the store. "Then I would say the website searching and the comparison" (In). Meanwhile, the use of the store channel was necessary for more complex, physical and utilitarian tasks during the fashion journey and during the stages of evaluation, purchase, delivery and return. "[. . . If it does n't look like it will really fit then the convenience of going in-store takes over, to be honest. I won't do it online" (Fg). The results highlighted a unique insight about omnichannel retailing whereby consumers engaged in simultaneous channel usage to enhance their shopping journey, for example using mobile app and store channels together. "[. . . If you are in store you can just go on the app and double check the price in another store [. . .]" (In).

4.4.2 Devices. The analysis of device usage provides insight for fashion retailers to ensure that their devices are optimised for the appropriate stages of fashion shopping. There was a clear preference for mobile phone usage across the journey and consequently retailers need to prioritise mobile for delivering an optimum customer-brand experience for a high involvement fashion audience. The usage of mobile phones specifically demonstrates that fashion consumers are also engaging in a customer decision-making journey more ubiquitously. For example, "[. . . ] That's something I use a lot more when I am on the go" (Fg). The findings also assert that omnichannel fashion consumers in-effect have the brand in their pocket and so this accessibility feeds high-involvement consumers' needs for continual information seeking as consumers can continuously engage with brands and the brand experience whenever they wish and while on-the-go. "I follow their PR which sort shows me behind the scenes on their photo shoots" (Fg). Finally, the use of laptop computers was complimentary to mobile usage across the journey with participants opting to use these for more task-related stages for example, research and comparison along with returns. For example, "That's for a bit more serious research it's bigger and quicker and less fiddly so l'd use that." (In).

\subsection{Emotion}

The study builds on the discussion of Wolny and Charoensuksai (2014) who suggest emotional responses are a key feature of customer decision journeys as the current work pinpoints the emotions that occur at each stage of a fashion decision journey and is one of the earliest studies to do so. The findings discovered that these fashion consumers experience an emotional rollercoaster of positive and negative feelings throughout their omnichannel experience. The emotions identified in the data collection were classed as either positive or negative based upon the work of Laros and Steenkamp (2005) 
Saraneva and S€a€aksj€arvi (2008). The results shed light on potentially weak stages of the omnichannel customer decisionmaking journey as priority areas for retailer improvement and correlate with operations literature on omnichannel.

Excitement was expressed at the outset of the inspiration stage with shoppers commencing their omnichannel journey with thoughts of seeking out "newness" and feeling open to new ideas and being in an exploratory frame of mind. "I think I'm quite excited and quite exploratory. Like I'm quite open to lots of ideas" (In). This finding was supported by the literature that suggests fashion information can stimulate excitement (McCormick and Livett, 2012; Rowley, 2009). The research and comparison stage, meanwhile, was filled with mixed emotions which were weighted towards the negative. Positive emotions included love and enjoyment reinforced the passion high-involvement customers possess towards fashion. "Yeah that's just what I enjoy doing. I enjoy the information as well. I wouldn't really see that as like searching for information I would see that more as enjoyment" (In). Negative affective experiences included: stress, annoyance, disappointment and fatigue among others. The feelings of fatigue correlate with Hollebeek (2011) who discussed that excessive brand engagement levels can lead to consumer fatigue. As journey progressed towards evaluation emotions were found to be more balanced as a result of shoppers finding a desired item with feelings of positivity and happiness. "When I went in store, found this one and tried it on I fell in love with it straight away and so it made me feel positive" (In). But disappointment and stress would also occur as a result of trying-on and evaluating garments in the store channel. Therefore, reflecting the reality of shopping when expectations were not met. Purchase was a an experience whereby participants recounted feelings of positivity, gratification and happiness at making a purchase. "I think I just like the instant gratification. It's done, I've got it" (Fg).

The delivery stage was filled with emotional highs and lows as participants noted the lag experienced between purchasing and receiving a product, therefore highlighting the lack of immediate gratification which this segment of consumers so craves. Initially, participants recounted positive emotions such as feeling happy; however, feelings of happiness were attributed to the evaluation of the product rather than the delivery itself. Likewise, participants explained that they were excited "You can see it coming to you a bit and it gives you that excitement" (Fg). Yet these feelings wore off and discussion was focused on feelings of annoyance and frustration with the delivery experience. However, it was the returns experience which created the most angst among all the journey stages. Customers experienced annoyance, stress and even hate. These negative feelings were associated with

the hassle of the returns process, the potential of having to pay for a return and the process of receiving a refund which was often delayed. "Em I think it's just, I hate sending things back and I always try to avoid returning things" (In). Thus, for fashion brands the delivery and returns stages present a priority area for improvement in the overall brand experience.

However, shopping journeys often ended on a high with the show and share stage as one of the most positive encounters during the journey. The sample described feeling confident, happy, good and even to the extent of feeling love. Participants felt confident in their fashion choices. Love within the show and share stage was attributed to consumers who were so motivated by this feeling that they opted to take further action related to their purchase, such as sharing across social media and endorsing brands. "It's kind of like because you tag the brand in it, it's sort of. . .it's not really advertising for them but it's sort of. It's almost like thanking them ... this is what I bought I love it kind of thing." (In). These analyses build upon the work of Hansen and Sia (2015) that using a brand hashtag is a tool for engagement.

\subsection{High-Involvement Fashion Consumer}

The research objectives sought to analyse how the shopping behaviour of involvement female fashion consumers has changed and the impact this has on decision-making. The data collection uncovers that the decision journey for highinvolvement consumers is one that is predicated on risk and that brand experience becomes very powerful in the omnichannel context.

4.6.1 A fashion decision journey predicated on risk. Fashion for this audience is a high-risk product category and a high stakes decision situation and therefore high involvement consumers are more vulnerable to risk and dissonance. To compensate, high-involvement consumers employ strategies to reduce risks throughout their journey. As the findings discussed, the research and comparison stage saw participants utilise an array of channels to research a product until they reach a point of saturation. "Which is probably why I feel like I have to use each of them [channels] because without one then my shopping journey is not complete" (In). This vulnerability and sensitivity to risk was also epitomised by participants who expressed a fear of missing out (FOMO). "I guess I want to see if there is anything that I am missing out [...]" (In). At the evaluation stage, shoppers also reduced risk by utilising wishlists and baskets to curate and contemplate items and recounted consulting peers. A journey predicated on risk is also compounded by the fact that the retail environment now transcends both physical and digital channels. For example, the extensive amount information and opinions available to consumers both from channels and through the journey being a social experience can hinder and fatigue as well as help consumers. 
What remains constant is that this consumer group still place high value on the store channel as part of their risk reduction strategy because of issues with fashion garment fit and sizing. At the purchase stage, participants recounted using channels to reduce risk. For instance, financial loss is minimised by shoppers seeking discount codes online channels and reviewing returns policies. The delivery stage evidenced further risk-averse behaviour and desire for immediate gratification by using facilities such as click and collect and expecting free delivery to reduce the risk of wasted time and cost. At the returns stage, consumers demonstrated the full extent of their risk and post-purchase dissonance reduction by returning of products as a result of over-ordering to reduce the potential of missing out on an item when re-ordering. At the show and share stage high involvement consumers would share images of their products including tagging brands via social networks as a validation strategy.

The data collection demonstrates that even at the outset of the journey risk-reduction strategies are at play. In this case brands serve as an important decision heuristic in the omnichannel journey as customers rely on their past experience with brands to aid them in their decision journey. A further finding was that the expectations that consumers possess of their omnichannel journey highlights ways in which consumers are actively seeking reassurance from fashion brands. Figure 1 provides a clear understanding of how risk can be managed as the findings recognise that consumers hold expectations of a seamless and consistent experience. However, it is important to recognise that the omnichannel context can also stimulate risks by empowering consumers with more channels and information than ever before which is a challenge of this new retailing era. Brands therefore need to be aware that high-involvement consumers possess a highly risk-averse mindset towards their shopping journey for fashion and marketing strategies must be designed to both reassure and mitigate risk as shoppers proceed along a decision path.

4.6.2 Brand experience. High involvement fashion consumers are those who are seeking brand experiences, who want to feel part of, connected to and immersed in, the brand through a stronger overall brand experience. This finding agrees with Jones and Runyan (2013) that positive brand experiences intensify the overall attitude towards the brand and supports the argument by Peltola et al. (2015) that omnichannel provides greater opportunities for brand engagement. High-involvement consumers are channel agnostic who perceive that omnichannel interactions lie not with each individual channel but instead form a cumulative brand experience in the consumer's mind. For example, "the idea of merging all of the channels into one so that they are one overall experience" (In). The finding supports Bhalla (2014) as omnichannel encompasses, "the full spectrum of channels". Therefore, the brand experience provides distinguishing feature of omnichannel versus multichannel since omnichannel retail should feature a specific mandate to manage the cross-channel brand experience. Ultimately, brand management in omnichannel fashion retail is about projecting a strong and a clear brand to reduce risk.

As discussed in this study, shoppers for fashion are now able to access the brand ubiquitously and have access to the brand "in their pocket". Omnichannel retail therefore facilitates high involvement behaviour among consumers, enabling them to feed their continual desire for fashion brand engagement. Taking a step further, omnichannel fashion retail experiences facilitate the "humanization" of brands as participants reported viewing the fashion brands as "friends" rather than simply as a retailer. The anthropomorphic quality of an omnichannel fashion brand manifested in the results, as brands having their own individual identity and style which serves as inspiration for consumers. For one participant, the human-like quality of a brand was highly evident as they spoke of Topshop, not as a brand, but as the "Topshop girl" and that the different channels reflected this "The Topshop girl and she is the girl you want to be. And the Instagram accounts are maybe what the Topshop girl would like. [.. .] think it's all about the brand [. . .]" (FIn). Anthropomorphism has been previously discussed in marketing as per Aaker et al. (2004) and Fugate, (2007). Now, omnichannel makes anthropomorphism even more real for consumers.

\section{Conclusion implications and limitations}

In terms of the empirical contribution high-involvement fashion consumers now engage in complex decision-making journeys and are accustomed to engaging with an array of channels. Despite such developments, the intrinsic nature of customer decision theory has remained relatively unchallenged. The consumer behaviour-based journey model presented extends the original consumer decision process to reflect fashion shoppers' interactions with the omnichannel retail environment. Furthermore, the paper brings together a unique constellation research themes of which have been discussed in the literature review to present an updated picture of decision-making journey for fashion. The paper asserts that the consumer decision process should not be discarded but revised and updated to reflect the influence of technology and fashion consumer preferences for shopping across channels.

Based upon an in-depth multi-method and qualitative approach, the research also finds that the contemporary decisionmaking for fashion features a complex and rich journey of not only stages both existing and new, but also channels, devices and affective experiences which combine to create a brand experience which customers can access whenever and however they choose. Therefore, the findings have contributed not only an understanding of omnichannel decision-making but brought the focus to fashion which is an emerging area of omnichannel research. The study finds that the omnichannel decision-making journey for high-involvement fashion consumers one predicated on risk and the findings and analysis 
highlight the strategies female fashion consumers use in order to mitigate decision-making risk which is useful to both researchers and practitioners alike.

The research suggests implications for practitioners by asserting that any fashion retailer is only as good as the weakest point in its customer journey. By using the customer decision journey retail marketers can uncover the cognitive paths of their customer audience and reveal clues why business performance may be not as desired. Practitioners can use the decision-making journey tool to evaluate a brand experience by looking at customers emotional experiences over the course of the journey in order to close the gap between actual and desired brand experience. Looking to key stages of the journey, the research identifies that the post-purchase phase of the decision journey is more extensive than first expected. The findings reveal a need for retailers to prioritise the delivery and returns stages as they represent major stress points for consumers. The framework also identifies which channels and devices are used during each stage journey. This understanding will enable retail staff and marketing teams to gauge what stage a consumer is at in their decision-making journey and optimise channels and devices to better fit customer needs at each decision stage. In doing so, marketers will be able tailor automated campaign strategies in a more sophisticated manner based upon the customer journey stages. The decision-making journey is a method by which to move a fashion retail brand further towards an omnichannel strategy and while it can be applied to large scale retailers this is also a useful and cost-effective tool for fashion retail SMEs to examine their current retail marketing strategy.

The limitations of this research include the small sample size, specific high-involvement fashion consumer segment type and geographical location. It is suggested that future research on this area investigates whether larger samples of highinvolvement female fashion consumers demonstrate a similar decision-making journey. There is also scope for further investigation into how concepts such as customer-brand engagement manifest across each channel.

References

Aaker, J., Fournier, S. and Brasel, S.A. (2004), "When good brands do bad”, Journal of Consumer Research, Vol. 31 No. 1, Narnia, pp. 1-16, doi: $10.1086 / 383419$.

Alexander, B. and Alvarado, D.O. (2014), "Blurring of the channel boundaries: the impact of advanced technologies in the physical fashion store on consumer experience", International Journal of Advanced Information Science and Technology, Vol. 30 No. 30, pp. 29-42, available at: http:// ualresearchonline.arts.ac.uk/9569/.

Aubrey, C. and Judge, D. (2012), "Re-imagine retail: Why store innovation is key to a brand's growth in the 'new normal, digitally-connected and transparent world", Journal of Brand Strategy, Vol. 1 No. 1, pp. 31-39. 
Auty, S. and Elliott, R. (1998), "Fashion involvement, self-monitoring and the meaning of brands", The Journal of Product and Brand Management, Vol. 7 No. 2, pp. 109-123, doi: 10.1108/ 10610429810216874.

Balasubramanian, S., Raghunathan, R. and Mahan, V. (2005), "Consumers in a multichannel environment: product utility, process utility and channel choice", Journal of Interactive Marketing, Vol. 19 No. 2, pp. 12-30.

Barnes, C. (2016), “Omni-channel retail - challenges and opportunities for packaging innovation”, in Burgess, P. (Ed.), Integrating the Packaging and Product Experience in Food and Beverages: A Road-Map to Consumer Satisfaction, Duxford. doi: 10.1016/B978-0-08-1003565.00004-8.

Barnes, L. (2013), “Fashion marketing”, Textile Progress, Vol. 45 Nos 2-3, Taylor \& Francis, pp. 182-207, doi: 10.1080/00405167.2013.868677.

Belk, R.W., Fischer, E. and Kozinets, R.V. (2013), "Qualitative consumer \& marketing research", available at: https://www.worldcat.org/title/qualitative-consumer-marketing-research/oclc/808492923.

Berman, B. and Thelen, S. (2004), "A guide to developing and managing a well integrated multi- channel retail strategy", International Journal of Retail \& Distribution Management, Vol. 32 No. 3, pp. 147-156.

Bernon, M., Cullen, J. and Gorst, J. (2016), "Online retail returns management Integration within an omni-channel distribution context", International Journal of Physical Distribution and Logistics Management, Vol. 46 Nos 6/7, pp. 584-60, doi: 10.1108/IJPDLM-01-2015-0010.

Bhalla, R. (2014), "The omni-channel customer experience: driving engagement through digitization", Journal of Digital and Social Media Marketing, Vol. 1, pp. 365-372.

Blakeney, J. (2016), "What are the benefits of creating an omnichannel brand experience", Journal of Brand Strategy, Vol. 5 No. 1 Spring, pp. 57-66.

Blackwell, R.D., Miniard, P.W. and Engel, J.F. (2006), Consumer Behavior, 10th ed., Thomson, Mason, Ohio.

Blazquez, M. (2014), "Fashion shopping in multichannel retail: the role of technology in enhancing the customer experience", International Journal of Electronic Commerce, Vol. 18 No. 4, pp. 97-116, doi: 10.2753/JEC1086-4415180404.

Bodhani, A. (2012), "Shops offer the e-tail experience”, Engineering and Technology, June, pp. 46-49. Browne, B.A. and Kaldenberg, D.O. (1997), "Conceptualizing self-monitoring: links to materialism and

product involvement", Journal of Consumer Marketing, Vol. 14 No. 1, pp. 31-44.

Breidbach, C.F., Brodie, R. and Hollebeek, L. (2014), "Beyond virtuality: from engagement platforms to

engagement ecosystems", Managing Service Quality, Vol. 24 No. 6, pp. 592-611.

Brynjolfsson, E., Hu, Y.J. and Rahman, M.S. (2013), "Competing in the age of omnichannel retailing", MIT Sloan Management Review, Vol. 54 No. 4, pp. 23-29, available at: https://sloanreview.mit. edu/article/competing-in-the-age-of-omnichannel-retailing/.

Cardoso, P.R., Costa, H.S. and Novais, L.A. (2010), "Fashion consumer profiles in the Portuguese market: involvement, innovativeness, selfexpression and impulsiveness as segmentation criteria", International Journal of Consumer Studies, Vol. 34, pp. 638-647, doi: 10.1111/j.1470- 6431.2010.00891.x

Carey, L., Cervellon, M.-C. and Doyle, S. (2014), I Shop where I Belong: The Influence of Self-Monitoring on Fashion Retailer Choice, Springer Gabler, Wiesbaden, pp. 1-21, doi: 10.1007/978-3-658-05313-0_1.

Carvalho, J.L.G.de and Campomar, M.C. (2014), "Multichannel at retail and omni-channel: challenges for marketing and logistics", Business and Management Review, Vol. 4 No. 3, pp. 103-113.

Chatterjee, P. (2010), "Multiple-channel and cross-channel shopping behaviour: role of consumer shopping orientations", Marketing Intelligence and Planning, Vol. 28 No. 1, pp. 9-24.

Cho, S. and Workman, J. (2011), "Gender, fashion innovativeness and opinion leadership, and need for touch: effects on multi-channel choice and touch/non-touch preference in clothing shopping", Journal of Fashion Marketing and Management, Vol. 15 No. 3, pp. 363-382, doi: 10.1108/ 13612021111151941. 
Christopher, M. (2016), "Logistics \& supply chain management”, available at: https://books.google.co.

uk/books?id5NIfQCWAAQBAJ\&dq52016pchristopherpomnichannelplogistics\&Ir5\&source5 gbs_navlinks_s.

Citrin, A.V., Stem, D.E., Spangenberg, E.R. and Clark, M.J. (2003), "Consumer need for tactile input", Journal of Business Research, Vol. 56 No. 11, pp. 915-922, doi: 10.1016/S0148-2963(01)00278-8.

Crosier, A. and Handford, A. (2012), "Customer journey mapping as an advocacy tool for disabled people: a case study", Social Marketing Quarterly, Vol. 18 No. 1, pp. 67-76.

Corbin, J. and Strauss, A. (2015), Basics of Qualitative Research: Techniques and Procedures for Developing Grounded Theory, Sage Publications, Thousand Oaks.

Cui, G., Bao, W. and Chan, T. (2009), "Consumers' adoption of new technology products: the role of coping strategies", Journal of Consumer Marketing, Vol. 26 No. 2, pp. 110-120, doi: 10.1108/ 07363760910940474.

Cummins, S., Peltier, J.W. and Dixon, A. (2016), “Omni-channel research framework in the context of personal selling and sales management: a review and research extensions", Journal of Research in Interactive Marketing, Vol. 10 No. 1, pp. 2-16.

Deloitte (2012), The changing face of retail, February, available at: http://www.deloitte.com/view/en_GB/uk/industries/consumerbusiness/28098047f3685310VgnVCM3000001c56f00aRCRD.htm[2 0.

Dholakia, R.R., Zhao, M. and Dholakia, N. (2005), "Multichannel retailing: a case study of early experience”, Journal of Interactive Marketing, Vol. 19 No. 2, pp. 63-74.

Drapers (2014a), Drapers Roundtable: Innovation in Fashion, 6 November, available at: http://www. drapersonline.com/insight/features/drapers-roundtable-innovation-in-fashion/5065831.artic le.

Elliott, S., Twynam, B. and Connell, S. (2012), Building for breakthroughs: the leadership of innovation in UK retail, Paper Presented at the Retail Week Conference, March, 2012, available at: https:// issuu.com/kornferryinternational/docs/building_for_breakthroughs_the_leadership_of_inno.

Frazer, M. and Stiehler, B.E. (2014), "Omnichannel retailing: The merging of the online and offline environment", Proceedings of the Global Conference on Business and Finance, Vol. 9 No. 1, pp. 655-657.

Fugate, D.L. (2007), “Neuromarketing: a layman's look at neuroscience and its potential application to marketing practice”, Vol. 7, pp. 385394, doi: 10.1108/07363760710834807.

Glaser, B. and Strauss, A. (1967), The Discovery of Grounded Theory, Weidenfeld and Nicholson, London.

Grewal, D., Levy, M. and Kumar, V. (2009), “Customer experience management in retailing: an organizing framework”, Journal of Retailing, Vol. 85 No. 1, pp. 1-14.

Hansen, R. and Sia, S.K. (2015), "Hummel's digital transformation toward omnichannel retailing: key lessons learned", MIS Quarterly Executive, Vol. 14 No. 1, pp. 51-66, doi: 10.1029/2001JB000246.

Hollebeek, L.D. (2011), “Demystifying customer brand engagement: exploring the loyalty nexus", Journal of Marketing Management, Vol. 27 Nos 7-8, pp. 785-807, doi: 10.1080/0267257X.2010. 500132.

Hoogveld, M. and Koster, J.M.D. (2016), "Implementing omnichannel strategies the success factor of agile processes", Advances in Management \& Applied Economics, Vol. 6 No. 2, pp. 25-38.

Hourigan, S.R. and Bougoure, U.S. (2012), "Towards a better understanding of fashion clothing involvement", Australasian Marketing Journal, Vol. 20 No. 2, pp. 127-135, doi: 10.1016/j.ausmj. 2011.10.004.

Hsieh, Y.-C., Roan, J., Pant, A., Hsieh, J.-K., Chen, W.-Y., Lee, M. and Chiu, H.-C. (2012), "All for one but does one strategy work for all? Building consumer loyalty in multi-channel distribution", Managing Service Quality, Vol. 22 No. 3, pp. 310-335.

Hubner, A., Wollenburg, J. and Holzapfel, A. (2016), "Retail logistics in the transition from multi- channel to omni-channel", International

Management, Vol. 46 Nos 6/7, pp. 562-583, available at: https://www.emerald.com/insight/ content/doi/10.1108/IJPDLM-08-20150179/full/html. 
Hure, E., Picot-Coupey, K. and Piveteau, L. (2016), “Channel design to enrich customers' shopping experiences: synchronizing clicks with bricks in an omni-channel perspective - the Direct Optic case", International Journal of Retail \& Distribution Management, Vol. 44 No. 3, pp. 336-368.

IDC Retail Insights (2010), "Five steps to profitable multichannel retailing", available at: c-community. com/retail/retailomnichannelstrategies/fivestepstoprofitablemultichannelretailing .

Jones, R.P. and Runyan, C. (2013), "Brand experience and brand implications in a multi-channel setting", The International Review of Retail Distribution and Consumer Research, Vol. 23 No. 3, pp. 265-290.

Jordaan, Y., Simpson, M.N. and Simpson, M.M.N. (2006), "Consumer innovativeness among females in specific fashion stores in the Menlyn shopping centre", Journal of Family Ecology and Consumer Sciences, Vol. 34 No. 1, South African Association for Family Ecology and Consumer Sciences 5 Suid-Afrikaanse Vereniging vir Gesinsekologie en Verbruikerswetenskappe, pp. 32-40, available at: https://www.ajol.info/index.php/jfecs/article/view/52887.

Kasper, H., Bloemer, J. and Driessen, P.H. (2010), "Coping with confusion: the case of the Dutch mobile phone market", Managing Service Quality, Vol. 20 No. 2, pp. 140-160, doi: 10.1108/09604521011027570.

Kent, A., Vianello, M., Cano, M.B. and Helberger, E. (2016), “Omnichannel fashion retail and channel integration”, in Handbook of Research on Global Fashion Management and Merchandising, IGI, pp. 398-419, doi: 10.4018/978-1-5225-0110-7.ch016.

Kim, H.-S. (2005), "Consumer profiles of apparel product involvement and values”, Journal of Fashion Marketing \& Management, Vol. 9 No. 2, pp. 207-220

Kim, H.-J., Ahn, S.-K. and Forney, J.A. (2014), "Shifting paradigms for fashion: from total to global to smart consumer experience", Fashion and Textiles, Vol. 1 No. 15, pp. 1-16.

Kitchen, P.J. and Schultz, D.E. (2009), "IMC: New horizon/false dawn for a marketplace in turmoil?", Journal of Marketing Communications, Vol. 15 Nos 2/3, pp. 197-204.

Koller, M. and Salzberger, T. (2006), "Extending the range of applicability of cognitive dissonance theory to the pre-decision phase - first findings based on a longitudinal study", in Charles Patti, J.D. (ed.), Advancing Theory, Maintaining Relevance, Proceedings of the ANZMAC Conference 2006, Brisbane, Australia, 2006, Queensland University of Technology, available at: https:// bach.wu.ac.at/d/research/results/36268/.

Koller, M., Salzberger, T. and Streif, G. (2007), Cognitive Dissonance in Retail versus E-Commerce - First Findings and Implications Monika Koller, Thomas Salzberger, Gerlinde Streif Vienna University of Economics and Business.

Kollmann, T., Kuckertz, A. and Kayser, I. (2012), “Author's personal copy Cannibalization or synergy?”, Consumers' Channel Selection in Online-Offline Multichannel Systems, doi: 10.1016/j.jretconser. 2011.11.008.

Kwon, W.-S. and Lennon, S.J. (2009), "Reciprocal effects between multichannel retailers' offine and online brand images", Journal of Retailing, Vol. 85 No. 3, pp. 376-390.

Kurt Salmon (2014), "Topshop takes the top spot in fashion omni-channel survey", available at: http:// www.kurtsalmon.com/en-gb/aboutnews-item/451/Topshop-takes-the- top-spot-in-fashion-omni- channel-survey- (accessed 06 May 2014).

La Pelle, N. (2004), "Simplifying qualitative data analysis using general purpose software tools", Field Methods, Vol. 16 No. 1, pp. 85-108, doi: $10.1177 / 1525822 \times 03259227$.

Laros, F.J.M. and Steenkamp, JBEM (2005), “Emotions in consumer behavior: a hierarchical approach", Journal of Business Research, Vol. 58 No. 10, pp. 1437-1445, doi: 10.1016/j.jbusres.2003.09.013.

Lazaris, C. and Vrechopoulos, A. (2014a), "From multi-channel to 'omnichannel' retailing: review of the literature and calls for research", 2nd International Conference on Contemporary Marketing Issues (ICCMI) 18-20 June 2014, Athens, pp. 1-6, available at:

https://www.researchgate.net/publication/267269215_From_Multichannel_to_Omnichannel_Retailing_Review_of_the_Literature_and_Cal Is_for_Research

Lazaris, C. and Vrechopoulos, A. (2014b) "Human-computer vs. consumer-store interaction in a multichannel retail environment: some multidisciplinary research directions", $\mathrm{HCl}$ in Business, Vol. 8527, pp. 339-349, available at: https://link.springer.com/chapter/10.1007/9783-319-07293-7_33. 
Lazaris, C., Vrechopoulos, A., Fraidaki, K. and Doukidis, G. (2014c), "Exploring the 'omnichannel' shopper behaviour", AMA SERVSIG, International Service Research Conference, June 13-15, Thessaloniki, Greece, available at:

https://www.researchgate.net/publication/267269007_Exploring_the_Omnichannel_Shopper_Behaviour.

Lazaris, C., Vrechopoulos, A. and Doukidis, G. (2015), "Mobile apps for omnichannel retailing: revealing the emerging showroom phenomenon', Mediterranean Conference on Information Systems (MCIS), Samos, Greece, pp. 1-17, available at : https://www.researchgate.net/profile/Chris_Lazaris/publication/282607049_Mobile_Apps_for_Omnichannel_Retailing_Revealing the_Emerging_Showrooming_Phenomenon/links/56aab0f308ae8f3865665f2d/Mobile-Apps-for-Omnichannel-Retailing-Revealing-theEmerging-Showrooming-Phenomenon.pdf.

Lemon, K.N. and Verhoef, P.C. (2016), "Understanding customer experience throughout the customer journey”, Journal of Marketing, Vol. 80, November, pp. 69-96, doi: 10.1509/jm.15.0420.

Levy, M. and Weitz, A. (2014), Retailing Management, 9th ed., The McGraw- Hill Education, New York.

Lowrey, T.M., Otnes, C.C. and McGrath, M.A. (2005), "Shopping with consumers: reflections and innovations", Elliott, R. (Ed.), Qualitative Market Research: An International Journal, Vol. 8 No. 2, pp. 176-188, doi: 10.1108/13522750510592445.

Malhotra, N. (2010), Marketing Research: An Applied Orientation, 6th Global, Pearson Education, Upple Saddle River, N.

McCracken, G. (1998), The Long Interview: Qualitative Research Methods Series 13, Sage, Newbury Park.

McCormick, H., Cartwright, J., Perry, P., Barnes, L., Lynch, S. and Ball, G. (2014), "Fashion retailing- past, present and future", Textile Progress, Vol. 46 No. 3, pp. 227-321.

McGoldrick, P.J. and Collins, N. (2007), "Multichannel retailing: profiling the multichannel shopper", International Review of Retail, Distribution and Consumer Research, Vol. 17 No. 2, pp. 139-158.

McCormick, H. and Livett, C. (2012), "Analysing the influence of the presentation of fashion garments on young consumers' online behavior", Journal of Fashion Marketing and Management: International Journal, Vol. 16 No. 1, pp. 21-41, doi: $10.1108 / 13612021211203014$.

Melero, I., Sese, F.J. and Verhoef, P.C. (2016), "Recasting the customer experience in today's omni- channel environment", Universia Business Review, Vol. 50, pp. 8-37.

Merrilees, B. (2016), "Interactive brand experience pathways to customer-brand engagement and value co-creation", The Journal of Product and Brand Management, Vol. 25 No. 5, pp. 402-408, doi: 10. 1108/JPBM-04-2016-1151.

Mintel (2014), “Clothing retailing - UK - October 2014”, available at: http://academic.mintel.com/ display/679590.

Mintel (2015), “The connected consumer - UK - may 2015", available at: http://academic.mintel.com/ display/737215/?highlight\#hit1.

Mirsch, T., Lehrer, C. and Jung, R. (2016), "Channel integration towards omnichannel Management: a literature review”, available at: alexandria.unisg.ch/publications/248768.

Molenaar, C. (2012), Shopping 3.0: Shopping, the Internet OR Both, Gower Publishing, Farnham.

Murfield, M., Boone, C.A., Rutner, P. and Thomas, R. (2017), "Investigating logistics service quality in omni-channel retailing", International Journal of Physical Distribution \& Logistics Management, Vol. 47 No. 4, Emerald Publishing, pp. 263-296, doi: 10.1108/IJPDLM-06-20160161.

Neslin, S.A. and Shankar, V. (2009), "Key issues in multichannel customer management: current knowledge and future directions", Journal of Interactive Marketing, Vol. 23 No. 1, pp. 70-81.

Neslin, S.A., Grewal, D., Leghorn, R., Shankar, V., Teerling, M.L., Thomas, J.S. and Verhoef, P.C. (2006), "Challenges and opportunities in multichannel customer management”, Journal of Service Research, Vol. 9 No. 2, pp. 95-112, doi: 10.1177/1094670506293559.

Nicholson, M., Clarke, I. and Blakemore, M. (2002), “'One brand, three ways to shop': situational variables and multichannel consumer behavior", International Review of Retail Distribution and Consumer Research, Vol. 12 No. 2, pp. 131-148, doi:

$10.1080 / 09593960210127691$. 
Park, H. and Cho, H. (2012), "Social network online communities: information sources for apparel shopping", Journal of Consumer Marketing, Vol. 29 No. 6, pp. 400-411.

Park, J. and Stoel, L. (2005), "Effect of brand familiarity, experience and information on online apparel purchase", International Journal of Retail and Distribution Management, Vol. 33 No. 2, pp. 148-160, doi: 10.1108/09590550510581476.

Patrıcio, L., Fisk, P., Cunha, F.E. and Constantine, L. (2011), "Multilevel service design: from customer value constellation to service experience blueprinting'", Journal of Service Research, Vol. 14 No. 2, pp. 180-200.

Patrıcio, L., Fisk, R.P. and Cunha, F.E. (2008), "Design- ing multi-interface service experiences: the service experience blueprint", Journal of Service Research, Vol. 10 No. 4, pp. 318-334.

Parsons, A.G. and Descatoires, E. (2016), "Retail marketing: a novel research agenda", Australian Marketing Journal, Vol. 24 No. 2, Elsevier Ltd, pp. 102-107, doi: 10.1016/j.ausmj.2016.05.005.

Patton, M.Q. (2002), Qualitative Research and Evaluation Methods. Qualitative Inquiry, 3rd ed., Sage Publications, London, doi: $10.2307 / 330063$.

Peltola, S., Vainio, H. and Nieminen, M. (2015), "Key factors in developing omnichannel customer experience with Finnish retailers", in FuiHoon Nah, F. and Tan, C.H. (Eds), HCl in Business, HCIB 2015, Lecture Notes in Computer Science, Springer, Cham, Vol. 9191, available at https:// link.springer.com/chapter/10.1007/978-3-319-20895-4_31\#citeas.

Peterson, M., Gr€one, F., Kammer, K. and Kirscheneder, J. (2010), “Multi-channel customer management: delighting consumers, driving efficiency", Journal of Direct, Data and Digital Marketing Practice, Vol. 12 No. 1, pp. 10-15, doi: 10.1057/dddmp.2010.16.

Picot-Coupey, K., Hure, E. and Piveteau, L. (2016), "Channel design to enrich customers' shopping experiences", in Kotzab Brusset, X. and Christop, H. (Eds), International Journal of Retail \& Distribution Management, Vol. 44 No. 3, Emerald Group Publishing, pp. 336-368, doi: 10.1108/ IJRDM-04-2015-0056.

Piercy, N. (2012), "Positive and negative cross-channel shopping behavior", Marketing Intelligence and Planning, Vol. 30 No. 1, pp. $83-104$, doi: 10.1108/02634501211193930.

Piotrowicz, W. and Cuthbertson, R. (2014), "Introduction to the special issue information technology in retail: toward omnichannel retailing", International Journal of Electronic Commerce, Vol. 18 No. 4, pp. 5-16, doi: 10.2753/JEC1086-4415180400.

Pookulangara, S., Hawley, J. and Xiao, G. (2011), “Explaining multi-channel consumer's channel- migration intention using theory of reasoned action", International Journal of Retail \& Distribution Management, Vol. 39 No. 3, pp. 183-202.

Puccinelli, N.M., Goodstein, R.C., Grewal, D., Price, R., Raghubir, P. and Stewart, D. (2009), “Customer experience management in retailing: understanding the buying process", Journal of Retailing, Vol. 85 No. 1, March, pp. 15-30.

Rangaswamy, A. and van Bruggen, G.H. (2005), Opportunities and challenges in multichannel marketing", Journal of Interactive Marketing, Vol. 19 No. 2, pp. 5-12.

Retail Systems Research (2013), “Omni-Channel 2013: the long road to adoption Benchmark Report”, available at: https://www.rsrresearch.com/research/omni-channel-2013-the-long-road-to-adoption.

Rose, S., Clark, M., Samouel, P. and Hair, N. (2012), "Online customer experience in e-retailing: an empirical model of antecedents and outcomes", Journal of Retailing, Vol. 88 No. 2, pp. 308-322.

Rigby, D. (2011), “The future of shopping”, Harvard Business Review, Vol. 89 No. 12, pp. 65-76. Rowley, J. (2009), “Online branding strategies of UK fashion retailers", Internet Research, Vol. 19 No. 3,

pp. 348-369, doi: 10.1108/10662240910965397.

Ryan, G.W. (2004), "Using a word processor to tag and retrieve blocks of text", Field Methods, Vol. 16

No. 1, pp. 109-130, doi: 10.1177/1525822X03261269.

Saraneva, A. and S€a€aksj€arvi, M. (2008), "Young compulsive buyers and the emotional roller-coaster in shopping", Young Consumers: Insight and Ideas for Responsible Marketers, Vol. 9 No. 2, pp. 75-89, doi: 10.1108/17473610810879657. 
Savastano, M., Barnabei, R. and Ricotta, F. (2015), "Going online while purchasing offline: an explorative analysis of omnichannel shopping behaviour in retail settings", Proceedings of the 12th International Conference on e-Business Engineering, Beijing, pp. 173-178.

Schramm-Klein, H., Wagner, G., Steinmann, S. and Morschett, D. (2011), "Cross-channel integration - is it valued by customers?", The International Review of Retail, Distribution and Consumer Research, Vol. 21 No. 5, pp. 501-511.

Savastano, M., Barnabei, R. and Ricotta, F. (2016), "Going online while purchasing offline: an explorative analysis of omnichannel shopping behaviour in retails settings", Proceedings of the International Marketing Trends Conference, Venice, January 2016, available at: https://pdfs. semanticscholar.org/958b/a0897f9bfb9ede048ed42062b16b54de800b.pdf, https://en.calameo.com/ $\mathrm{read} / 00031243452 \mathrm{~d} 8 \mathrm{aff06072}$

Schoenbachler, D.D. and Gordon, G.L. (2002), "Multi-channel shopping: understanding what drives channel choice", Journal of Consumer Marketing, Vol. 19 No. 1, pp. 42-53.

Schr€oder, H. and Zaharia, S. (2008), "Linking multi-channel customer behavior with shopping motives: an empirical investigation of a German retailer", Journal of Retailing and Consumer Services, Vol. 15 No. 6, pp. 452-468, doi: 10.1016/j.jretconser.2008.01.001.

Shaw, D.R. and Towers, N. (2015), "Understanding how millennial shoppers decide What to buy. Gloucester", available at: www.maybe.xyz/whitepaper.

Solomon, M.R. and Rabolt, N.J. (2009), Consumer Behaviour in Fashion, 2nd ed., Pearson Prentice Hall, Upple Saddle River.

Stone, M., Hobbs, M. and Khaleeli, M. (2002), '“Multichannel customer management: the benefits and challenges”, Journal of Database Management, Vol. 10 No. 1, pp. 39-52.

Summers, J.O. (1970), "The identity of women's clothing fashion opinion leaders", Journal of Marketing Research, Vol. 7 No. 2, SAGE PublicationsSage CA, Los Angeles, CA, pp. 178-185, doi: 10.1177/ 002224377000700204.

Van Bruggen, G.H., Antia, K.D., Jap, S.D., Reinartz, W.J. and Pallas, F. (2010), "Managing marketing channel multiplicity", Journal of Service Research, Vol. 13 No. 3, pp. 331-340, doi: 10.1177/ 1094670510375601.

Verhoef, P.C., Lemon, K.N., Parasuraman, A., Roggeveen, A., Tsiros, M. and Schlesinger, L.A. (2009), "Customer experience creation: determinants, dynamics and management strategies”, Journal of Retailing, Vol. 85 No. 1, pp. 31-41.

Verhoef, P.C., Neslin, S.C. and Vroomen, B. (2007), "Multi channel customer management: understanding the research-shopper phenomenon", International Journal of Research in Marketing, Vol. 24, pp. 129-148.

Verhoef, P.C., Kannan, P.K. and Inman, J.J. (2015), "From multi-channel retailing to omni-channel retailing. Introduction to the special issue on multi-channel retailing", Journal of Retailing, Vol. 91 No. 2, New York University, pp. 174-181, doi: 10.1016/j.jretai.2015.02.005.

Vieira, V.A. (2009), "An extended theoretical model of fashion clothing involvement", Journal of Fashion Marketing and Management, Vol. 13 No. 2, pp. 179-200, doi: 10.1108/ 13612020910957707.

Wolny, J. and Charoensuksai, N. (2014), "Mapping customer journeys in multichannel decision- making", Journal of Direct, Data and Digital Marketing Practice, Vol. 15 No. 4, Nature Publishing Group, pp. 317-326, doi: 10.1057/dddmp.2014.24.

Workman, J.E. and Studak, C.M. (2006), "Fashion consumers and fashion problem recognition style", International Journal of Consumer Studies, Vol. 30 No. 1, pp. 75-84, doi: 10.1111/j.1470-6431. 2005.00451.x.

Xia, L. (2010), “An examination of consumer browsing behaviors”, Qualitative Market Research: An International Journal, Vol. 13 No. 2, pp. 154-173, doi: 10.1108/13522751011032593. 
Dr Samantha Lynch is a senior lecturer, researcher and consultant in consumer decision-making behaviour and omnichannel marketing. Her research and consultancy seeks to examine the how and why behind shopper behaviour with a focus on customer journeys. Samantha Lynch is the corresponding author and can be contacted at: samantha@drsamlynch.co.uk

Professor Liz Barnes is the Head of School (Manchester Fashion Institute) at Manchester Metropolitan University and is a professor of Fashion Marketing. Her current research expertise lies in the field of fashion marketing. More recently Liz has published research in the areas of fashion consumer behaviour, omnichannel customer journey, eWOM, fashion influencers, social media marketing, luxury fashion, modest fashion and country of origin.

The authors would like to acknowledge the intellectual debate amongst fellow fashion marketing academics in the design and fashion business subject group at the University of Manchester with particular thanks to Dr Helen McCormick and Dr Delia Vazquez. 